which has proved very efficient has also been constructed for attachment to a motor-scythe, and no special skill is required in its use. Experimental work on the subject is being continued, and it seems possible that given good weather conditions, complete eradiction of bracken may ultimately be obtained after a single cut.

\section{Rationing of Manufacturers' Supplies}

Iт has recently been suggested to us that in placing orders for material or apparatus, an authority for the order should always be quoted in order to secure release of material. In an article on "The Manufacturers' Order Book" by "Sala" which appears in the Electrical Review of November 8, the whole problem raised by questions of priority is discussed. Almost every manufacturer of materials required in the war effort has to decide whether to refuse orders for the time being or to limit the acceptance of orders so as to bring them into line with his estimated output. The manufacturer can obtain but little guidance from his customers as to the urgency of their requirements, for each will rightly demand preference in view of the material being required for urgent Government work. It may also happen that material ordered through the usual trade channels is required for some vitally important part of the war effort and demands priority over orders received direct from Government departments. One way out of the difficulty is for the manufacturer to see that each customer will get a portion of his requirements. This rationing of supplies rarely solves the difficulties. The manufacturer realizes the inadvisability of refusing orders particularly as he generally has no means of authenticating their vital importance in comparison with the uncompleted priority orders still on his books. He feels that the responsibility of limiting or reducing the amounts specified in a consumer's order should not be left to the manufacturer.

\section{Mosquito Control in Great Britain}

THE Ministry of Health has recently published a "Memorandum on Measures for the Control of Mosquito Nuisances in Great Britain" (No. 238, Medicine, 1940) by Lieut.-Col. J. A. Sinton and Mr. P. G. Shute. While mosquitoes may carry malaria in certain circumstances in Britain, as hap. pened during and after the War of 1914-18, it is mainly because of the nuisance caused by the bites that anti-mosquito measures are undertaken in Great Britain. Of the 29 recorded species, eight are so rare or so seldom bite man that they may be considered unimportant from the public health point of view. Anopheles maculipennis is the potential carrier of malaria and during the past twenty-five years more than 500 cases of the disease have been proved to have been locally contracted in almost every instance through its agency. The habits, economy, and means of control of this and other British mosquitoes are dealt with in this memorandum. The information given is up to date and has obviously been carefully collated. If anti-mosquito measures are to be applied effectively and economically the species concerned must be identified and its habits taken into account. Specimens are identified free of charge at the Malaria Laboratory of the Ministry of Health or at the British Museum (Natural History). Once a given species is named the advice given for its control may be followed. The memorandum, it may be added, is to be obtained from H.M. Stationery Office or through any bookseller, price $6 d$. net.

\section{A Parachute Fishing Net}

Dr. J. F. G. WHEELER, director of the Biological Station at Bermuda, has succeeded in designing a workable net in the form of a parachute for catching small deep-sea planktonic organisms. The novel idea of a fishing net without a towing line is adapted from the method used by Prof. Maurice Ewing in his work on the sub-sedimentary rocks beneath the sea. The net fishes upside down. At the top is a fine mesh followed by a wider weave net; it then broadens out to a canvas-like material which has metal 'eyes' punctured into the bottom. From these 'eyes' are attached ropes or bridles. These come down in a $\mathrm{V}$ fashion to a small cord to which is attached a wire receptacle in which is placed a large lump of rock salt. Beneath this are suspended two weights. At the top of the net, and inside it, is a funnel-like pipe leading into a bucket. Affixed to the top of the bucket are a float (a can filled with petrol) and a flag.

The net is nine feet three inches across its mouth and nearly thirty feet long. The two concrete weights total $138 \mathrm{lb}$. The apparatus is easily thrown into the sea. On its downward journey the net swells out and opens in a parachute-like form, retaining its shape on its descent. It catches as it goes down the minute plankton which enters the mouth and passes into the bucket through the funnel. The net touches the bottom. The salt has by this time dissolved (the requisite amount having been roughly calculated) and the weights are released. The closed parachute is then brought to the surface by the float. The net was successfully used at a depth of more than 1,000 fathoms. Its advantages over a tow-net are that it can be handled easily by a small crew in calm weather, and can be left to itself while the boat is elsewhere. Also that the specimens are in better condition when brought to the surface.

\section{The American Museum of Natural History}

THE Americas for the moment are fortunate in being so far removed from the theatre of war as to be able to continue scientific investigation in the field, even though it be only on a restricted scale. During the past summer, the American Museum of Natural History has sent expeditions for zoological and palæontological research to Alaska, Kansas, Texas and Dakota (Science, August 16, 1940). The expedition under Dr. Walter Grainger, curator of palæontology in the Museum, which is exploring the Big Badlands of South Dakota for fossils of the threetoed horse, the pygmy rhinoceros, and cats, especially the sabre-toothed tiger, is accompanied by 